\title{
A novel alien invasive species introduction, Clerodendrum paniculatum Linn (Pagoda) Lamiaceae, in a tropical African forest
}

Omomoh Eromosele Bernard ( $\sim$ benomong@yahoo.com )

Federal University of Technology, Akure, Nigeria

\section{Leah Brown}

Insight Lab, Faculty of Information and Media Studies, Western University, London, Ontario, N6A 3K,

Canada

\section{Karst Meiger}

Herbarium Frisicum Scloolstraat 19B8471 CC Wolvega Netherlands

\section{Victor A. J. Adekunle}

1Department of Forestry and Wood Technology, Federal University of Technology, Akure, Nigeria

\section{Ganiyu Oboh}

FUTA herbarium, Centre for Research and Development (CERAD), Federal University of Technology, Akure, Nigeria

\section{Short Report}

Keywords: conservation ecology, Clerodendrum paniculatum, pagoda flower, alien plant species, invasive species in Africa, Strict Nature Reserve, biodiversity in Africa, biodiversity in Nigeria, parks management, Forest Plantation

Posted Date: March 9th, 2021

DOl: https://doi.org/10.21203/rs.3.rs-307017/v1

License: (c) (i) This work is licensed under a Creative Commons Attribution 4.0 International License. Read Full License 


\section{Abstract}

We record a novel introduction of Clerodendrum paniculatum in Africa. The novel species appears to have a negligible impact within the new environment. In this communication, we describe the novel alien species and the environment to which it has been introduced.

\section{Introduction}

The introduction of novel alien species into new habitats was not a global issue until such habitats began to lose three integral parts of biodiversity, such as ecosystem, species, and genetic diversity, to novel alien species (CBD 2009). Consequently, biological invasion introduces novel alien species to native plant communities (Satterthwaite et al. 2007), forms species colonies (Augusto et al 2001, Luzuriaga et al 2005), and causes differential characteristics in genetic validation, all contributing to biodiversity losses (McNeely et al 2001, Mack et al 2000). The losses brought about by novel alien species invasion are undoubtedly a critical issue in the world economy, specifically developing countries in Africa (Nuñez \& Anıbal 2010). Due to provenance variation, little is still known of the effective mechanism to eradicate the level of novel alien species invasion (Engiberger 2009, Flory 2019) in developing countries. Therefore, biodiversity conservation of indigenous plant ecosystems requires obtaining an adequate sample of unperturbed ecosystem types of an endangered species in perpetuity, which becomes an example of the original forest that is used for the Strict Nature Reserve (Omomoh et al 2019, Adekunle et al 2013, Onyekwelu et al 2008). Incidentally, studies show that novel alien species colonize different protected areas such as Strict Nature Reserve (Wekhanya 2016, Lone 2019).

In the present study, an introduction of the alien plant species Clerodendrum paniculatum Linn, commonly known as Pagoda flower, and one of the 150 original species in the genus Clerodendrum was detected and collected for the first time in an African forest. C. Paniculatum is abundant in tropical and subtropical Asia where it is commonly encountered and widely cultivated for its medicinal uses. There is no current information regarding the presence of $C$. paniculatum in Africa. Additionally, lyama et al (2015) did not report any collections of this species either in forests, fields, or gardens, which places this plant among the lesser-known alien species in Nigeria (Adekunle 2009). The species is a well-known invader in several parts of the world (Englberger 2009), native to Europe and Australia, and is predominant in Asian countries like Bangladesh, Laos, China, Cambodia, Sri Lanka, Vietnam, Malaysia, Indonesia Taiwan (Prashithet al 2018, Leeratiwong 2011, Bhat 2014, Melapu 2015). The genus Clerodendrum (Linn.-F.T.A. 5: 292; B. Thomas in Engl. Bot. Jahrb. 68: 1.1936) was formerly placed in the family Verbenaceae but is now placed in the family Lamiaceae (Cantino et al., 1992 and Harley et al., 2004).

This genus is composed of c.a. 400 species of mostly shrubs or trees, erect or rarely climbing, deciduous or evergreen. They are found mostly in the tropics and sub-tropics across Asia, Europe, Africa, and the Americas (Shou-liang and Gilbert 1994). Thirty species have been recorded in Africa alone (FWTA 1963), 34 species across China (Shou-liang and Gilbert 1994). In Nigeria, 18 species are recorded according to Flora of West Tropical Africa, and 9 of these species are indigenous (Gbile et al 2002). 


\section{Materials And Methods}

\section{Sampling Design}

In March 2020, we collected samples of Clerodendrum paniculatum at two sites; Forest plantation and Strict Nature Reserve at the forest reserve, Nigeria. Four temporary sample plots of $400 \mathrm{~m}^{2}$ (two at each site) were haphazardly selected along the vegetation road edge where $C$. paniculatum was found. The first $10 \mathrm{~m}$ line of $400 \mathrm{~m}^{2}(20 \mathrm{~m}$ by $20 \mathrm{~m}$ ) was stationed to start from the first $C$. paniculatum, where it was sighted at the spatial area from the road edge to the smaller spatial area of the site (adjacent to the road edge). The scientific name and family followed the flora of West Tropical Africa (Hutchinson et al 1963).

\section{Data analyses}

The plant species were categorized into their life forms using Hutchinson et al (1963). The percentage of species relative density was calculated using:

$\mathrm{RD}=(\mathrm{ni} / \mathrm{N}) \times 100(1)$

Where $\mathrm{RD}$ = species relative density,

$\mathrm{ni}=$ number of individuals of species $\mathrm{i}$,

$\mathrm{N}=$ total number of all plant species in the entire community.

\section{Specimen}

We first discovered $C$. paniculatum while collecting specimens for herbarium collection (Omomoh et al 2019). We visually estimated $C$. paniculatum cover at each site. Specimens of flowering parts and leaves were collected in September of 2014, brought to the herbarium, and examined while still fresh. Latitude and longitude for each site were taken using a Garmin GPS 60. After a thorough plant examination, collections were identified as Clerodendrum. For more specific identification, we sent specimens to Aleksi Baznekian (Joseph Keefe Herbarium, USA), who identified the specimen as C. paniculatum L. Additionally, we cross-checked our specimen with the studies of Deori et al (2012) and Prashith \& Sudharshan (2018).

\section{Distribution in Nigeria: South West Ondo, Akure forest reserve}

This Akure forest area is humid sub-tropical with a mean temperature of $26^{\circ} \mathrm{C}$ (range of $19^{\circ} \mathrm{C}-34^{\circ} \mathrm{C}$ ). The wet season is from March to November (2500 mm bimodal rainfall pattern) and the dry season from December to February (Omomoh 2018, Omomoh et al 2019, Omomoh et al 2020). The Akure forest reserve is a tropical successional rainforest situated between two communities, Aponmu and Obada in Owena. Local government encompasses the two study sites, Forest plantation, and Strict Nature Reserve, where the novel alien species was first located and collected. 
The novel species is a tropical evergreen shrub that was found in dry and mixed deciduous forests along the major roadside in two different regions (Forest Plantation and marginal area of theStrict Nature Reserve; Figure 1). This part of the forest has been going through succession following human disturbance since the initiation of the forest reserve (Onyekwelu. et al 2008). The $C$. paniculatum species are more scanty and sturdy in the Strict Nature Reserve than in the Forest Plantation where the species was growing bigger and taller. The species height varied from one $C$. paniculatum to another $(75 \mathrm{~cm}$ to $1.3 \mathrm{~m})$ due to the degree of sunlight exposure received.

\section{Diagnostic character}

\section{Clerodendrum paniculatum Linnaeus, Mant. PI. 90.1767.}

Shrubby tree (Figure 2, 3a and 3b) about $2-3 \mathrm{~m}$ high; stem stout in a square cross-sectional size or obtusely quadrangular. Flowering parts bear numerous large, red-orange, flowers with terminal inflorescences. The thyrses, called panicles, are often up to $45 \mathrm{~cm}$ long. The tubular flower is $1.2-2 \mathrm{~cm}$ long with five small lobes. The leaves are opposite, large at the base and becoming smaller upwards; subrotund to cordate at the base, and palmately lobed (3-7) at the margins.

\section{Results And Discussion}

\section{Species richness and diversity of the study area}

Considering the distribution of Clerodendrum paniculatum in several parts of the world as both native and invasive connotes that this novel alien species originates not from Africa, and nevertheless this study reveals where it was found in Africa for the first time. The different land-use type effects on species distribution and establishment in these new habitats gave us the larger number of species at one site over the other.

The total families are shown in Tables $1 \&$ 2. Twenty-one (21) families were encountered within the Forest Plantation, and fifteen (15) in Strict Nature Reserve (SNR).This shows that between the two different sites, the family with the highest number of plant species was found in the legumimosae (Caesalpinoideae, Detariodeae, and Papilionideae) with 7 different plants species. But within the sites, plant numbers from Table 1 show $C$. paniculatum was the second most abundant plant species, with a relative density of $14.12 \%$, after Sida acuta Burm. F., a native plant, with a relative density of $15.97 \%$. The species comparison between the two tables shows that the proliferation of $C$. paniculatumwas rather alarming in Table 2. The reason for this rapid growth and distribution may have been associated with what Randhi and Reddy (2013) described as an intermediate, tolerant,plant capacity in their study. Light and spatial distributions are associated factors more incidental toterritorial adaptation and tolerance in the Forest Plantation than in the protected area of the Strict Nature Reserve. This is seen as a result of a partial or closed canopy in Strict Nature Reserve. This dynamic change is in corroboration with Lone et al (2019), which states "invasive species typically are more tolerant than the native species to a wide range 
of environmental conditions and possess unique biological traits that offer them various competitive advantages."

We estimated the Shannon-Weiner diversity index and species evenness for the two sites. The Strict Nature Reserve was less diverse and less even $\left(H^{\prime}=2.48, E=0.41\right)$ than the Forest Plantation $\left(H^{\prime}=2.9\right.$, $\mathrm{E}=0.48$ ). Most of the species in the Forest Plantation are agricultural weeds (Perera, 2005).

Table 1. Plant species, relative frequency and relative density of Forest plantation 


\begin{tabular}{|c|c|c|c|c|}
\hline Family & Scientific name & Life form & $\mathrm{nHa}^{-1}$ & $\mathrm{RD}$ \\
\hline \multirow[t]{2}{*}{ Acanthaceae } & Acanthus montanus (Nees) T. Anders. & Forb & 11 & 2.5 \\
\hline & Asystasia vogeliana Benth. & Forb & 22 & 5.1 \\
\hline Amarantanceae & Cyathula prostrata (Linn.) Blume & Forb & 36 & 8.3 \\
\hline \multirow[t]{2}{*}{ Ampelidaceae } & Cissus kouandeensis A. Chev. & Climber & 13 & 3.0 \\
\hline & Cissus petiolata Hook. f. & Climber & 2 & 0.5 \\
\hline Apocynaceae & $\begin{array}{l}\text { Holarrhena floribunda (G. Don) Dur. \& Schinz APD } \\
\text { acc }\end{array}$ & Sapling & 1 & 0.2 \\
\hline Araceae & Culcasia scandens P. Beauv. & Climber & 22 & 5.1 \\
\hline Arecaceae & Elaeis guineensis Jacq. & Sapling & 11 & 2.5 \\
\hline Asclepiadaceae & Parquetina nigrescens (Afzel.) Bullock & Climber & 1 & 0.2 \\
\hline \multirow[t]{2}{*}{ Asteraceae } & Chromolaena odorata (L.) R. M. King \& H. Rob. & Forb & 13 & 3.0 \\
\hline & Vernonia cinerea (Linn.) Less. & Forb & 9 & 2.1 \\
\hline \multirow[t]{4}{*}{ Caesalpinioideae } & Acacia ataxacantha DC. & Climber & 5 & 1.2 \\
\hline & Albizia adianthifolia (Schum.) W. F. Wight & Sapling & 1 & 0.2 \\
\hline & Albizia zygia (DC.) J. F. Macbr. & Sapling & 1 & 0.2 \\
\hline & Senna hirsuta (L.) H.S. Irwin \&Barneby & Sapling & 2 & 0.5 \\
\hline \multirow[t]{2}{*}{ Commelinaceae } & Aneilema beniniense (P. Beauv.) Kunth & Forb & 5 & 1.2 \\
\hline & Commelina erecta L. subsp. Erecta & Forb & 3 & 0.7 \\
\hline Convolvulaceae & Merremia aegyptia (Linn.) Urban & Climber & 2 & 0.5 \\
\hline Cucurbitaceae & Momordica charantia Linn. & Climber & 11 & 2.5 \\
\hline Dioscoreceae & Dioscorea preussii Pax & Climber & 7 & 1.6 \\
\hline Euphorbiaceae & Manihot esculentaCrantz & Shrub & 17 & 3.9 \\
\hline \multirow[t]{2}{*}{ Lamiaceae } & Clerondendrum paniculatum Linn & Sapling & 61 & 14.1 \\
\hline & $\begin{array}{l}\text { Solenostemon monostachyus var. graniticola (A. } \\
\text { Chev.) Brenan }\end{array}$ & Forb & 6 & 1.4 \\
\hline \multirow[t]{2}{*}{ Malvaceae } & Sida acuta Burm. f. & Forb & 69 & 16.0 \\
\hline & Sida urens Linn. & Forb & 9 & 2.1 \\
\hline Moraceae & Ficus exasperata Vahl & Sapling & 1 & 0.2 \\
\hline Papilionoideae & Centrosema pubescens Benth. & Climber & 14 & 3.2 \\
\hline
\end{tabular}




\begin{tabular}{|lllll|} 
& $\begin{array}{l}\text { Desmodium adscendens (Sw.) DC. var. } \\
\text { adscendens }\end{array}$ & Forbs & 18 & 4.2 \\
\hline Poaceae & Panicum maximum Jacq. & Graminoid & 31 & 7.2 \\
\hline Portulacaceae & Talinum triangulare (Jacq.) Willd. & Forb & 17 & 3.9 \\
\hline Sterculiaceae & Theobroma cacao Linn. & Sapling & 11 & 2.5 \\
\hline
\end{tabular}

$\mathrm{n} \mathrm{ha}^{-1}=$ number of stems per hectares, $\mathrm{RD}=$ relative density.

Table 2. Plant species, relative frequency and relative density of Strict nature reserve 


\begin{tabular}{|c|c|c|c|c|}
\hline Family & Name & $\begin{array}{l}\text { Life } \\
\text { Form }\end{array}$ & $\mathrm{nHa}^{-1}$ & RD \\
\hline Amarantaceae & Cyathula prostrata (Linn.) Blume & Forb & 81 & 19.8 \\
\hline \multirow[t]{2}{*}{ Annonaceae } & Cleistopholis patens (Benth.) Engl. \& Diels & Sapling & 11 & 2.689 \\
\hline & Funtumia elastica (Preuss) Stapf & Sapling & 1 & 0.244 \\
\hline Apocynaceae & Rauvolfia vomitoria Afzel. & Sapling & 2 & 0.489 \\
\hline Araceae & Culcasia scandens P. Beauv. & Forb & 7 & 1.711 \\
\hline Asteraceae & Tithonia diversifolia Hemsl. A. Gray & Forb & 78 & 19.07 \\
\hline Bombacaceae & Ceiba pentandra (Linn.) Gaertn. & Sapling & 23 & 5.623 \\
\hline Detarioideae & Anthonotha macrophylla P. Beauv. & Sapling & 4 & 0.978 \\
\hline Euphorbiaceae & Mallotus oppositifolius (Geisel.) Müll. Arg & Shrub & 27 & 6.601 \\
\hline Lamiaceae & Clerodendrum paniculatum $\mathrm{L}$. & Sapling & 3 & 0.733 \\
\hline \multirow[t]{2}{*}{ Meliaceae } & $\begin{array}{l}\text { Entandrophragma utile (Dawe \& Sprague) } \\
\text { Sprague }\end{array}$ & Sapling & 17 & 4.156 \\
\hline & Khaya grandifoliola C. DC. & Sapling & 48 & 11.74 \\
\hline Menispermaceae & $\begin{array}{l}\text { Jateorhiza macrantha (Hook. f.) Exell \& } \\
\text { Mendonca }\end{array}$ & Climber & 14 & 3.423 \\
\hline Polygalaceae & Carpolobia lutea G. Don & Sapling & 14 & 3.423 \\
\hline Rubiaceae & Cuviera longiflora Hiern & Sapling & 2 & 0.489 \\
\hline \multirow[t]{2}{*}{ Sapindaceae } & Allophylus africanus P. Beauv. & Sapling & 8 & 1.956 \\
\hline & Blighia sapida Konig & Sapling & 4 & 0.978 \\
\hline \multirow[t]{5}{*}{ Sterculiaceae } & Cola gigantea A. Chev. var. Gigantean & Sapling & 3 & 0.733 \\
\hline & $\begin{array}{l}\text { Mansonia altissima (A. Chev.) A. Chev. var. } \\
\text { altissima }\end{array}$ & Sapling & 32 & 7.824 \\
\hline & Pterygota macrocarpa K. Schum. & Sapling & 2 & 0.489 \\
\hline & Sterculia tragacantha Lindl. & Sapling & 2 & 0.489 \\
\hline & Triplochiton scleroxylon K. Schum. & Sapling & 19 & 4.645 \\
\hline
\end{tabular}

$\mathrm{n} \mathrm{ha} \mathrm{A}^{-1}=$ number of stems per hectares, $\mathrm{RD}=$ relative density.

Distribution and species range of Clerodendrum paniculatum at the study area 
Clerodendrum paniculatum was identified in the Strict Nature Reserve and the Forest Plantation. $C$. paniculatum is becoming more adaptive in the Forest Plantation as land managers have stated that several efforts of attempting to remove $C$. paniculatum have not worked. $C$. paniculatum appears to be much more abundant in the Forest Plantation than in the Strict Nature Reserve.

Our studies have shown that $C$. paniculatum, though fewer in number, pose a threat to the current status of the Strict Nature Reserve. It may have been as a result of the great adaptability of this plant to interact with the native species of the stable forest (Omomoh et al 2019) at the forest edge. Open forest canopy can as well encourage wind-borne seed of novel alien species to proliferate in a new site (Perera 2005, Pickett \& McDonnell 1989), as was in the case of Forest Plantation. This is certainly another prospective challenge in the management of the Strict Nature Reserve, as it may pose a greater danger of extinction to native biodiversity hereafter.

\section{Species presence on the new environment}

This study is the first report of $C$. paniculatum in Africa. It does not currently appear to have a large impact on the community that it is novel to, and thus we do not currently categorize this plant species as an 'invasive'. Despite this, $C$. paniculatum is currently cited as invasive in the following countries:

Singapore, Cuba, Hawaii, French Polynesia, Micronesia, Fiji, Palau, New Guinea, the Solomon Islands, and Western Samoa (CAB 2020). Previous research has shown that the invasiveness of $C$. paniculatum is driven in part via its root proliferation ability (Chong et al 2009, Randall 2017, Pier 2020, Powo 2020, Oviedo \& Gonzalez-Oliva 2015). Our current assessment of $C$. paniculatum as a novel alien species with non-problematic impact (Williamson 1999) is similar to the Davis and Thompson (2000) type 3 and 7 colonizer categories.

Although novel species range expansion on these new regions is not invasive, unexpected mass dispersal resulting in expansion of their range (e.g., environmental change) following long time disturbance could quickly lead to invasion. Consequently, Engiberger (2009) reported the phytogeographical scenario of this plant in Oceania: French Polynesia, Guam, Marshall Island, Nauru, Palau Papua, New Guinea, Samoa, and the Solomon Islands. The Federated States of Micronesia lists $C$. paniculatum as distributed across the islands of Pinpelap, Pohnpei, and Chuuk. Nevertheless, reports of novel alien species colonization in new areascould greatly assist conservation efforts in mitigating invasions at the early stage in Africa. However, little or lack of scientific information on invasive plant species in developing countries leads to a shortfall in scientific data for international uses (Nuñez \& Pauchard 2010, Nuñez. et al 2019). To overcome this challenge, a collaboration between countries and researchers is needed to address this emerging menace by identifying and sharing scientific information on novel alien species in different jurisdictions, as well as current best management practices to handle them (Brundu et al 2020).

\section{Declarations}

\section{Acknowledgements}


Our appreciation goes to Aleksi Baznekian whose contribution to plant identification of this plant, Clerodendrum paniculatum is without measured. Special thanks to FUTA herbarium, Federal University of Technology, Akure, and IFE herbarium, Obafemi Awolowo University, Ile-Ife, Nigeria, whose facility also contribute to the plant identification

\section{Conflict of Interest}

We have no conflict of interests.

\section{Orcid}

Bernard. E. Omomoh https://orcid.org/0000-0002-0506-4973

\section{Data Availability}

Nil

\section{References}

Adekunle VAJ (2009) Diversity and abundance of lesser-known plant species of food and ethnomedicinal potential in tropical rainforest ecosystem of southwest Nigeria. Acta Hort. 806, ISHS, pp 685- 694.DOI: 10.17660/ActaHortic.2009.806.85

Adekunle VAJ, Olagoke AO, Ogundare LF (2013) Logging impacts in tropical

lowland humid forest on tree species diversity and environmental conservation. Appl. Ecol. Env. Res, 11(3), 491-511.

Bhat GK (2014) Flora of South Kanara; Dakshina Kannada and Udupi districts of

Karnataka, Current Science-Bangalore: 107, 9; 1603. ISSN: 0011-3891

Brundu G, Pauchard A, Pyšek P, Pergl J, Bindewald AM, Brunori A, Canavan S,

Campagnaro T, Celesti-Grapow L, Dechoum M, Dufour-Dror J, Essl F, Flory SL, Genovesi P, Guarino F, Guangzhe L, Hulme PE, Jager H, Kettle CJ, Krumm F, Langdon B, Lapin K, Lozano V, Roux JJ, Novoa A, NuñezMA, Porte AJ, Silva JS, Schaffner U, Sitzia T, Tanner R, Tshidada N, Vitkova M, Westergren M, Wilson JRU, Richardson DM (2020) Global guidelines for the sustainable use of non-native trees to prevent tree invasions and mitigate their negative impacts. NeoBiota 61: 65-116. doi: 10.3897/neobiota.65.58380http://neobiota.pensoft.net

CAB (2020) CAB International datasheets Clerodendrum paniculatum (pagoda flower). 
Invasive species compendium, detailed coverage of invasive species threatening livehoods and the environment worldwide. https://www.cabi.org/isc/datasheet/119784

Cantino PD, Harley RM, Wagstaff SJ (1992) Genera of Labitae: Status and

Classification. In R.M. Harley and T. Reynolds (Eds.). Advances in Labiate Science. Royal Botanic Gardens, Kew, 511-523 pp.

Chen S, Michael GG (1994) Verbenaceae, Flora of China 17: 1-49.eFloras.org.

Chong KY, Tan HTW, Corlett RT (2009) A checklist of the total vascular plant flora of

Singapore: native, naturalised and cultivated species, Singapore: Raffles Museum of Biodiversity Research, National University of Singapore, pp 273 pp.

https://lkcnhm.nus.edu.sg/app/uploads/2017/04/flora_of_singapore_tc.pdf

Davis MA, Thompson K (2000) Eight ways to be a colonizer; two ways to be an

invader. Bulletin of the Ecological Society of America, 81: 226-230

Deori C, Roy, DK, Talukdar, SR (2012) Clerodendrum paniculatum L. (Verbenaceae):

A new record to Northeast India from Barnadi wildlife sanctuary, Assam. J. Econ. Taxon. Bot., 36 (4): 835 836.

Englberger K (2009) Invasive weeds of Pohnpei: A guide for identification and public

awareness. Kolomia. Federated States of Micronesia: Conservation Society of Pohnpei, pp 2

Gbile ZO, Soladoye MO (2002) Vernacular names of Nigerian plants, Forestry

Research Institute of Nigeria, Ibadan, pp 75-76

Harley RM, Atkins S, Budantsev PD, Cantino PD, Conn BJ, Grayer R, Harley,

MM, DeKok R, Kresstovskaja T, Morales R, Paton AJ, Ryding O, Upson T (2004) Labiatae. In: K. Kubitzki (Ed.). The Families and Genera of Vascular Plants: Flowering Plant-Dicotyledons, vol. 7, Germany: Springer-Verlag, 1-199 pp

Hutchinson J, Dalziel JM, Hepper, FN (1963) Flora of West Tropical Africa, Crown Agents,

Millbank, London. S.W.1. 2: 1613-1622

lyamah PC, Idu M (2015) Ethnomedicinal survey of plants used in the treatment of 
malaria in Southern Nigeria. Journal of Ethnopharmacology,173, 287-302.

http://dx.doi.org/10.1016/j.jep.2015.07.008

Kew (2013) Clerodendrum paniculatum (pagoda flower), Kew Royal Botanic Gardens

(online). London, Kew, UK

Leeratiwong C, Chantaranothai P, Paton, AJ (2011) A synopsis of the genus

Clerodendrum L. (Lamiaceae) in Thailand, Tropical Natural History, 11(2), 177-211.

Melapu VK, Joginipelli S, Naidu, BVA, Darsey, J (2015) A comparative

phylogenetic evaluation of chloroplast ITS sequences to analyze the bioactivity in medicinal plants: A case study of Clerodendrum plant genus (Lamiaceae), Austin J Comput Biol Bioinform, 2(1), 1011.

Nuñez MA, Pauchard A (2010) Biological invasions in developing and developed

Countries: does one model fit all?.Biol Invasions. 12:707-714.

DOI 10.1007/s10530-009-9517-1.

Akure Forest Reserve, Ondo State, Nigeria. Mtech Thesis, Federal University of Technology, Akure, Nigeria, 24-25 pp

Omomoh BE, Adekunle VAJ, Aigbe PD, Ademoh FO, Omomoh BM (2020)

Evaluation of soil seed bank-vegetation and regeneration potential of Tectona grandis L. f. plantation (Taungya farm) in Akure forest reserve, Ondo State, Nigeria. Tropical Plant Research. 7(1): 37-45. DOI: 10.22271/tpr.2020.v7.i1.006

Omomoh B, Adekunle V, Lawal A, Akinbi. O (2019) Tree species diversity and

regeneration potential of soil seed bank in Akure forest reserve, Ondo state, Nigeria. Taiwania, 64(4): 409416. DOI: $10.6165 /$ tai.2019.64.409

Onyekwelu JC, Mosandl R, Stimm B (2008) Tree species diversity and soil status of

primary and degraded tropical rainforest ecosystems in South-Western Nigeria. J. Trop. For. Sci, 20(3), 193-204.

Oviedo PR, González-Oliva L (2015) National list of invasive and potentially invasive plants

in the Republic of Cuba - 2015. (Listanacional de plantasinvasorasypotencialmenteinvasorasen la República de Cuba - 2015). Bissea: BoletínsobreConservación de Plantas del JardínBotánico Nacional de Cuba. 9 (Special Issue No. 2), 1-88. 
Powo (2000) Plants of the world online. In. Plants of the world online, London. UK: Royal

Botanic garden, Kew. http://www.plantsoftheworldonline.org

Prashith KTR, Sudharshan SJ (2018) Ethnobotanical uses, phytochemistry and

biological activities of Clerodendrum paniculatum L. (Lamiaceae): A comprehensive review, Journal of Drug Delivery and Therapeutics; 8(5), 28-34

DOl:http://dx.doi.org/10.22270/jddt.v8i5-s.1930

Randall (2017) A global compendium of weeds, (Ed. 3) [ed. By Randall, R. P]. Perth,

Australia: R. P. Randall.iii + 3653 pp.

The Plant List (2013) Version 1.1. Published on the Internet; http://www.theplantlist.org/

(accessed 1st Januar

Williamson M (1999) Invasions Ecography22:5-12.

\section{Figures}




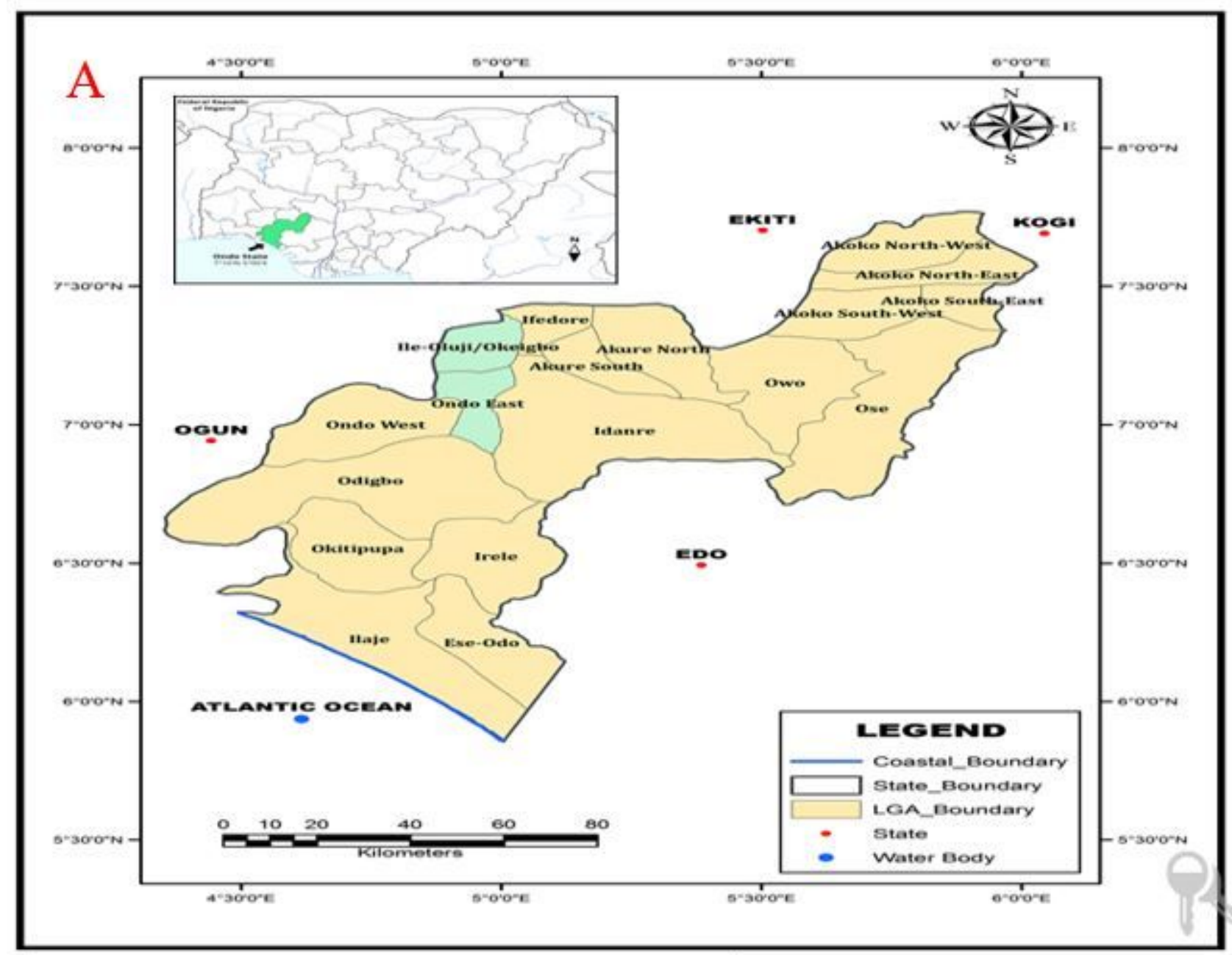

B

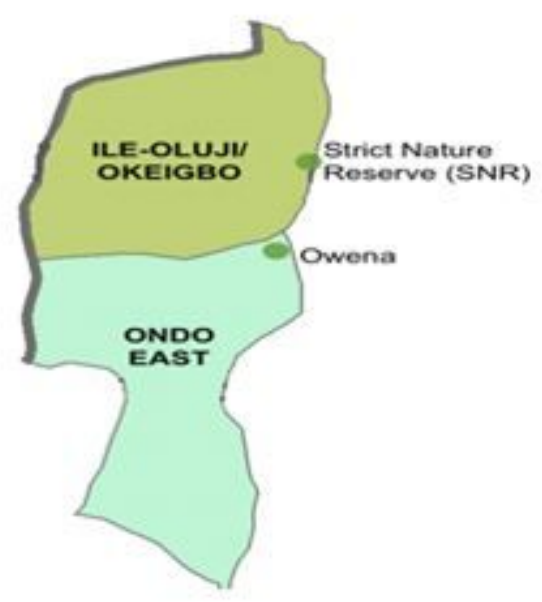

Figure 1

Map of the two study sites. The green area showed the specific study area while the points, Strict Nature Reserve (SNR) and Owena (Forest Plantation) depict the points where the studies were carried out. 


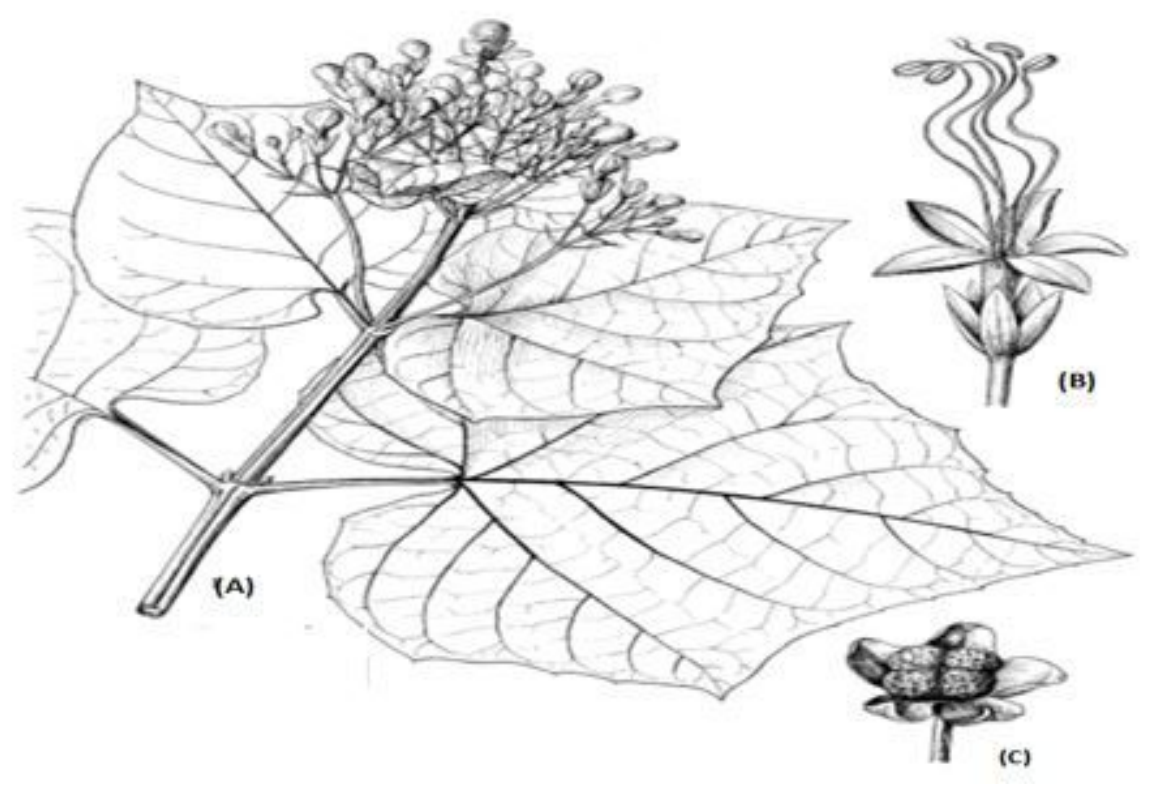

Figure 2

(a) Clerodendrum paniculatum Linnaeus (b) Flowering branch, (c) Fruit. (Chen et al 1994). Systematics reference: Clerodendrum paniculatum L, Mant. PI. 1: 90. 1767; Blume, Bijdr. Fl. Ned. Ind.: 811. 1826; Walp., Repert. Bot. Syst. 4: 102. 1845; Schauer in A. DC., Prodr. 11: 668. 1847; Miq., Fl. Ind. Bat. 2: 879. 1858; C.B. Clarke in Hook.f., Fl. Brit. India 4: 593. 1885; Brandis, Indian Trees: 508. 1906; King \& Gamble, J. Asiat. Soc. Bengal 74: 838. 1909; Hall.f., Meded. Rijks-Herb. 37: 81. 1918; H.J. Lam, Verben. Malay. Archip.: 295. 1919; Bakh. in H.J. Lam \&Bakh., Bull. Jard. Bot. Buitenzorg, ser. 3, 3: 92. 1921; Ridl., Fl. Malay Penins. 2: 628. 1923; P'ei, Mem. Sci. Soc. China 2(3): 144. 1932; Dop in Lecomte, FI. Indo-Chine 4(7): 864. 1935; H.R. Fletcher, Bull. Misc. Inform., Kew 1938: 429. 1938; Back. \&Bakh.f., Fl. Java 2: 609. 1965; Burkill, Dict. Econ. Prod. Malay Penins. 1: 593. 1966; Congdon, Nat. Hist. Bull. Siam Soc. 30(2): 185.1982; Hsiao, Fl. Taiwan: 423. 1978; Kochummen in Ng, Tree Fl. Mal. 3: 304. 1978; Moldenke\& A.L. Moldenke in Dassan. \&Fosberg, Rev. Handb. Fl. Ceyl. 4: 417. 1983; Keng, Con. Fl. Singapore: 193. 1990; Hô, CâycoViêtnam 2: 1055. 1993; Chen \& M.G. Gilbert in Wu \& Raven, Fl. China 17: 36. 1994; A. Rajendran \& P. Daniel, Ind. Verbenaceae: 128. 2002; Phuong in N.T. Ban et al., Fl. Vietnam 3: 293. 2005. VolkameriaangulataLour., Fl. Cochinch: 389. 1790. (Leeratiwong. et al 2011) 

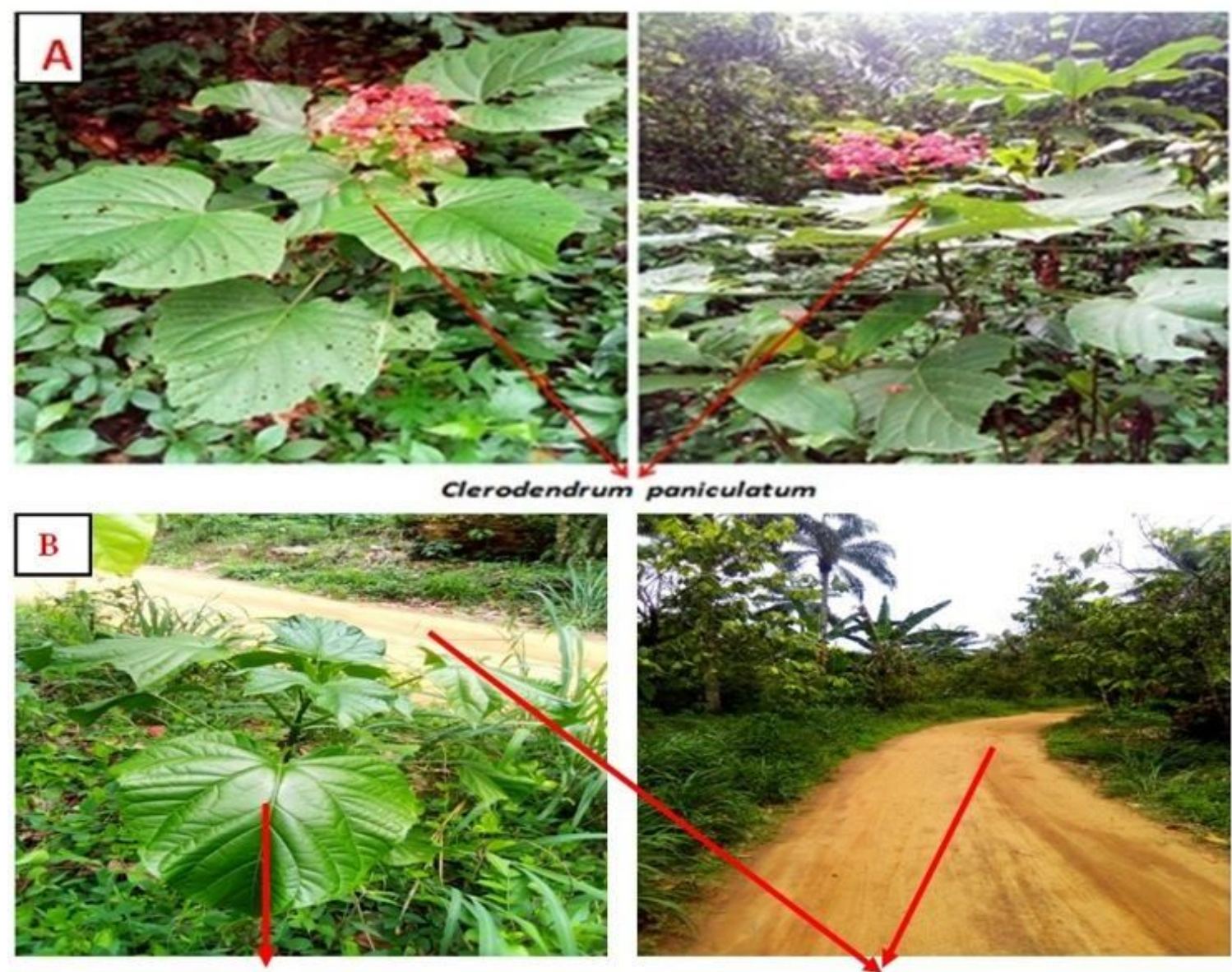

Clerodendrum paniculatum

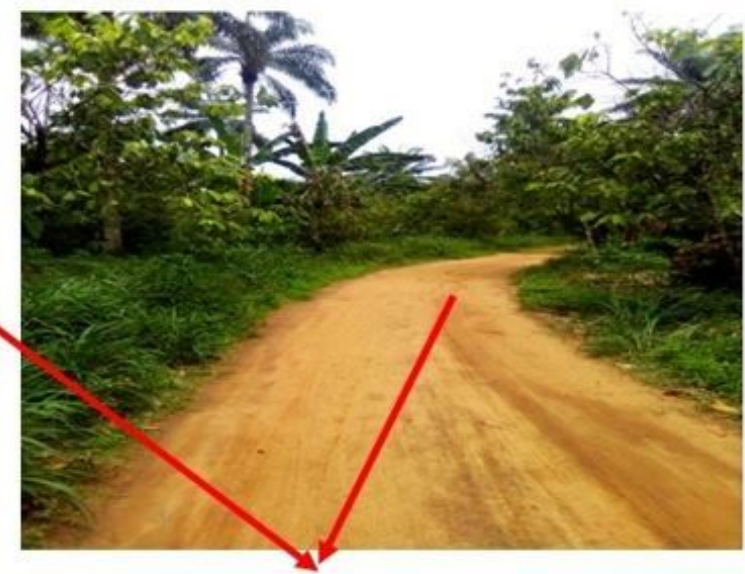

Roadside Forest plantation

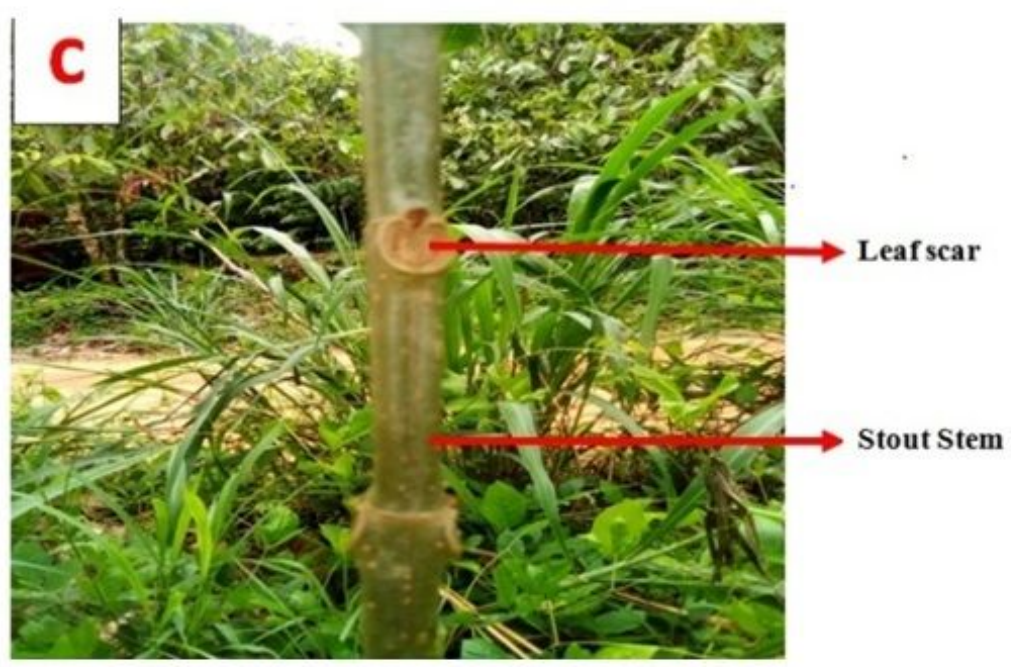

Figure 3

Figure 3a: Clerodendrum paniculatum at the forest verge on the strict nature reserve (3b). Forest plantation roadside where Clerodendrum paniculatum were found. Figure 3c: The stout stem, node once borne leaf scar 